\title{
An Analysis of Pragmatic Presupposition in Maturity Episode on Golden Ways Show
}

\author{
Maria Olivia Christina Sianipar ${ }^{1}$ \\ ${ }^{1}$ HKBP Nommensen University
}

\begin{tabular}{|c|c|}
\hline ARTICLE INFO & ABSTRACT \\
\hline Article history: & \multirow{12}{*}{$\begin{array}{l}\text { Pragmatics is concerned with the study of meaning as communicated } \\
\text { by speaker or writer and interpreted by a listener or a reader. It has } \\
\text { consequently more to do with the analysis of what people mean by } \\
\text { their utterances. Describing the types of presupposition by the } \\
\text { utterances in a talk show named Golden Ways is the objective of this } \\
\text { research. The subject of this research is a talk show entitled maturity. } \\
\text { The data are some utterances said by the speaker and heard by the } \\
\text { hearer. Utterances between the host and the audiences from this show } \\
\text { can show the presupposition. The writer analyzed the types of } \\
\text { presupposition by Yule's theory (1996) to find out what types are } \\
\text { often used in this talk show. The data analysis is conducted by } \\
\text { classifying and categorizing the data to find the inferences. The } \\
\text { writer uses a descriptive method because it describes the } \\
\text { presupposition in the talk show and it was suitable to the purpose of } \\
\text { the study. As Monsen stated (2008: 5) the descriptive research often } \\
\text { illustrates a relevant but non quantified topic involving a well- } \\
\text { focused research question. It generates narrative data that describe } \\
\text { words instead of numbers. The writer has found all six types of } \\
\text { presupposition which applied in this talk show. This research shows } \\
\text { that presupposition always exist in utterances. }\end{array}$} \\
\hline Received Feb 072000 & \\
\hline Revised Apr 19,2020 & \\
\hline Accepted Jun 08, 2020 & \\
\hline Keywords: & \\
\hline Pragmatics, & \\
\hline Presupposition, & \\
\hline Show & \\
\hline Clonflict of Interest: & \\
\hline None & \\
\hline Funding: & \\
\hline None & \\
\hline
\end{tabular}

Corresponding Author: Maria Olivia Christina Sianipar, HKBP Nommensen University, Medan, Indonesia. E-mail: mariasianipar919@yahoo.com

Copyright $@$ Association of Language Teachers in Southeast Asia. All rights reserved

\section{Introduction}

\subsection{Introduce the Problem}

Language, in addition to serving to communicate information, actually has a variety of functions, including the expression of emotion, the maintenance of social ties, and even the performance of action (a statement such as I declare you guilty uttered by a judge). Furthermore, in any context, a variety of factors, such as the age, sex, and social class of the interlocutors and their relationships of intimacy and power, influence the form of language used. We will consider this fairly wide-open field from two different perspectives.

"Pragmatics is one of those words (societal and cognitive are others) that give the impression that something quite specific and technical is being talked about when often in fact it has no clear meaning." Pragmatics is the study of the functions of language and its use in context. For example, in the context of a driver and a passenger in a car stopped at a traffic light, the phrase The light is green uttered by the passenger is not simply a description but performs the pragmatic function of advising the driver to step on the gas pedal and move into the intersection. A presupposition is a proposition whose truth is taken for granted by the producer of an utterance and which must be known and taken account of for the utterance to make sense to an interpreter. Take the case of Pete has stopped smoking. Someone using this sentence to 
make a bona fide literal statement takes it for granted that Pete was previously a smoker, although this is not explicitly stated. And the presumption that Pete had been a smoker is necessary for the sentence to make sense to a hearer, even if that fact was not previously known.

The writer analyzed the presupposition in movie/YouTube; in this case the writer chose a talk show Golden Ways by a motivator Mario Teguh with the title Maturity. There are two reasons why this study is worthwhile to be researched. First, speaker need to be understood about presupposition to help him produces utterances that easy to understand by listener. A speaker has to make the sentence that its presupposition is known by the listener to avoid the misinterpretation between the speaker and listener. Second, when the speaker delivers his message to the listener in unstated sentence, the listener doesn't understand the meaning of the speaker's utterance from the sentence itself, so we have to add presupposition in true context. Besides that the listener also needs to understand about presupposition to help him catching the speaker's message. The use of presupposition is not only in daily life but also in movie conversation. Related to the phenomena above, there are many possible research problems that can be studied, such as types, uses and function of presupposition.

\section{Literature Review}

These are the four areas that pragmatics is concerned with. To understand how it got to be that way, we have to briefly review its relationship with their areas of linguistic analysis. There are kinds of pragmatics by George Yule (1996:4).

1. Pragmatics is the study of speaker meaning.

Pragmatics is concerned with the study of meaning as communicated by a speaker (or writer) and interpreted by a listener (or reader). It has consequently, more to do with the analysis of what people mean by their utterances than what the words or phrases in those utterances might mean by themselves.

2. Pragmatics is the study of contextual meaning.

This type of study necessarily involves the interpretation of what people mean in particular context and how the context influences what is said. It requires a consideration of how speakers organize what they want to say in accordance with who they are talking to, where, when, and under what circumstances.

3. Pragmatics is the study of how more gets communicated than is said.

This approach also necessarily explores how listeners can make inferences about what is said in order to arrive at an interpretation of the speaker's intended meaning. This type of study explores how a great deal of what is unsaid is recognized as part what is communicated. We might say that it is the investigation of invisible meaning.

4. Pragmatics is the study of the expression of relative distance.

This perspective then raises the question of what determines the choice between the said and unsaid.

The basic answer is tied to the notion of distance, whether it is physical, social, or conceptual, implies shared experience. On the assumption of how closer distant the listener is, speakers determine how much needs to be Pragmatics is the study of the expression of relative distance.

Types of presupposition by George Yule (1996)

1. The existential presuppositions

It is not only assumed to be present in possessive constructions (for example your car $\gg$ you have a car), but more generally in any definite noun phrase. By using any of the expression, the speaker is assumed to be committed to the existence of the entities named such as: The king of Sweden, the cat, the girl next door, The Counting Crows. 
2. The Factive Presupposition

Everybody knows that q' with q as the presupposition. The presupposed information following the verb like 'know' can be treated as a fact and is described as a Factive Presupposition. A number of other verbs, such as 'realize' in a. and 'regret' in b. as well as phrases involving 'be' with 'aware' in c. odd in d., glad in e. have factive presuppositions. For examples:

a. She didn't realize she was ill.>> She was ill.

b. We regret telling him >> We told him.

c. I wasn't aware she was married $>>$ She was married.

d. It isn't odd he left early $>>$ He left early.

e. I am glad that it's over $>>$ It is over.

3. The Lexical Presupposition

The use of one form with its asserted meaning is conventially interpreted with the presupposition that another (non asserted) meaning is understood. Each time you say that someone managed to do something, the asserted meaning is that the person is succeeded in some way. When you say that someone didn't managed, the asserted meaning is that the person did not succeed. In both cases however, there is a presupposition (non asserted) that the person tried to do that something.

So, managed is conventially interpreted as asserting succeeded and presupposing tried. Other examples, involving the lexical items 'stop', 'start', and 'again'; are presented with their presuppositions in:
a. He stopped smoking >> He used to smoke
b. They started smoking $>>$ They weren't complaining before.
c. You are late again >> You were late before.

4. Structural Presupposition.

In this case certain sentence structures have been analyzed as conventionally and regularly presupposing that part of the structure is already assumed to be true. We might say that speakers can use such structure to treat information as presupposed (i.e. that is to be true) and hence to be accepted as true by the listener. For example, the wh question construction in English, as shown in:

a. When did he leave? >> He left.

b. When did you buy the bike? >> You bought the bike.

These examples are conventionally interpreted with the presupposition that information after the $w h$ form \{i.e. When and Where \}is already known to be the case.

5. A Non Factive Presupposition

A Non Factive Presupposition is one that is assumed not to be true. Verbs like 'dream', 'imagine', ‘ pretend 'as shown as a, b, c are used in presupposition that what follows is not true. For examples:

a. I dream that I was rich >>I was not rich.

b. We imagine that we were in Hawai > we were not in Hawai

c. He pretends to be ill $>\mathrm{He}$ is not ill.

6. The Counter Factual Presupposition

Meaning that what is presupposed is not only not true, but is the opposite of what is true, or contrary to facts. A conditional of structure of the type shown in this example such as 
'If you were my friend, you would have helped me >> you are not my friend.

The existence of non factive presuppositions is part of an interesting problem for the analysis of utterances with complex structures, generally known as the projection problem.

\section{Method}

This research had been conducted by using a descriptive method because it described and it was suitable to the purpose of the study. According to Monsen (2008: 5) the descriptive research often illustrates a relevant but non quantified topic involving a well-focused research question. It generates narrative data that describe words instead of numbers.

The data is collected from a talk show named Golden Ways through video in YouTube. In collecting data, the writer exploits the technique of observation. There are some steps in collecting the data. First, watch the video in order to find the presupposition from the conversation. Then, mark the sentence that contains presupposition in the video. The writer analyzed the data with model analysis by Yule (1996). Collecting data; the writer designed the technique of analyzing data as follows: classifying the types of presupposition and analyzing the meaning of presupposition. Second, this is the process of translating. The data are in Bahasa Indonesia, so she translates the data into English. Third, for some points she changes the sentence from positive form into negative form in some kinds of presupposition. This step is to check the presupposition in the sentence. Finally, she explained some presuppositions as suggested by Yule and shared knowledge which used by Mario Teguh to motivate an audience. This research also had been conducted by using a descriptive method because it described and it was suitable to the purpose of the study..

\section{Results and Discussion}

The writer has obtained data and then analyzed them. The data is categorized by the type of its presuppositions. Here are analyses of the data; the writer classified them into 6 types of presuppositions suggested by Yule (1996):

\section{The existential presupposition}

Episode "Maturity", segment 1

a. Angga punya masalah. (Angga's problem) (Angga has a problem).

b. Angga tidak punya masalah. (Angga does not have any problem).

c. Ada Angga. (There is Angga).

Situation: In this first segment, Mario Teguh listens to the audience named Angga about his problems. In every segment, there is a discussion session. In this session, the audience is welcomed to ask Mario Teguh in front of the audience on the stage.

In this utterance, Mario Teguh gives solutions to Angga's problems. The existential presuppositions of both sentences are Angga. Angga still exists even though the sentence is negated. This is one of the existential presupposition's characteristics that there is an existing noun in the utterance.

There is a shared knowledge between Mario Teguh and the audience that 'there is Angga'. This shared knowledge used by Mario Teguh to motivate the audience. He wanted the audience to know that there is Angga who has problems. Mario Teguh also explained how to be an independent person. The audience will not only know that there is Angga's problem, but also they will get advice how to have a good character due to the problems of Angga.

\section{Factive Presupposition}

Episode "Maturity", segment 2

Situation: In segment 2, Mario Teguh explains how important to be patient. He did not only answer the question but also shared knowledge between host and the audiences.

a. Banyak orang meyadari bersabar lebih baik daripada membalas.

(Many people realize that being patient is better than doing revenge.)

b. Banyak orang tidak menyadari bersabar lebih baik daripada membalas.

(Many people do not realize that being patient is better than doing revenge.)

c. Bersabar lebih baik daripada mendendam 
(Being patient is better than doing revenge).

The word 'realize' in Mario Teguh's utterance refers to a fact condition. The fact condition is 'being patient is better than doing revenge' even they were realize or do not realize. Realize is a word that affects a fact condition, so this is a factive presupposition.

The shared knowledge between Mario Teguh and the audience is 'being patient is better than doing revenge'. This shared knowledge used by Mario Teguh in his utterance to motivate the audience. He explains when people being patient, they will get much happiness and piece. This is not about win and loses but the important thing is to make beautiful life with forgetting the mistakes of people by being patient. Because everybody does mistakes, nobody is perfect.

\section{Lexical Presupposition}

Episode 'Maturity' segment 2

Situation: In segment 2, Host asked "how to control our emotion?" Then Mario Teguh explained it. He did not only answer the question, but also shared knowledge between Mario Teguh, host, and audience.

a. Agus berhasil berusaha di Jakarta.

(Agus managed to do something in Jakarta)

b. Agus tidak berhasil berusaha di Jakarta

(Agus did not manage to do something in Jakarta).

c. Managed is conventionally interpreted as asserting 'succeeded' and presupposing 'tried'.

The phrase 'manage' indicates the sentence (a) has a lexical presupposition.

A shared knowledge between Mario Teguh and the audience is 'a man who can control his emotion is a man who can manage his undertakings and problems. Mario Teguh motivates the audience to have a good character such as having good emotional that way someone can control emotional, to face everything that happens in life, this way someone can get success easily.

\section{Structural presupposition}

Episode 'Maturity' segment 2

Situation: Mario Teguh explains how we change our attitude to be a mature person. This is one of his utterances.

a. Kapan kalian dewasa?

b. When did you get mature?

c. Presupposes that they already got mature

The structure of an interrogative sentence in (a) has been conventionally interpreted in the presupposition. The information which exists after the wh-question has been known as true. 'When' and 'where' is the question word that indicates as structural presupposition.

'Get mature' is the shared knowledge between Mario Teguh and the audience. The sentence (a) is Mario Teguh's utterance. In this segment, the audience asking a question to Mario Teguh 'how to get a happy life?' Here, he motivates the audience that many people try to get happiness by doing many things that is good and bad or wrong and right. In other words he explains that many people can choose good things when they already get mature in the way of thinking. People who already get mature can face and control everything happens in many different ways, of course in a good way. This kind of people can get happiness easily.

\section{Non Factive Presupposition}

(1) Episode 'Maturity' segment 4

Situation: Mario Teguh explains how to get success in life.

(a). Rudi memimpikan bahwa dia sangat terkenal.

(Rudi dreamed that he was very famous.)

(b). Rudi tidak memimpikan bahwa dia sangat terkenal

(Rudi did not dream that he was very famous.)

(c). Rudi was not famous.

The word 'dream' is one of non-truth conditional presupposition. In non-factive presupposition, the information after the word 'dream' assumed to be untrue. The word 'famous' is something unreal because it is only exists in the mind. The word 'dream' indicates a non-factive presupposition. Here, Mario Teguh has a 
shared knowledge with the audience that to have a dream is good, especially to have a dream being a famous person. It means that you are going to do good things not only for your sake but for many people this way you will get famous someday.

\section{Counter Factual Presupposition}

It is the assumption that what is presupposed is not only untrue, but is the opposite of what is true, or contrary to facts. For instance, some conditional structures, generally called counterfactual presupposition, that the information, in an if clause, is not true at the time of utterance.

Episode "Maturity", segment 1

Situation: In this segment another audience named Sukron is given a chance to talk about his problem. Mario Teguh listens to Sukron's story and then Mario gave some wonderful ideas to Sukron.

a. Sekiranya kamu anak saya, saya tidak akan mengijinkan kamu melakukan ini.

b. If you were my son, I would not allow you to do this.

c. Presupposes that he is not my son. Out of these two presuppositions, only the first one is an actual presupposition and the second one carries information that is reported.

The writer gives some examples from all kinds of presuppositions as a summary for making presupposition easy to understand.

I. The existential Presupposition; It is the assumption of the existence of the entities named by the speaker.

1. Aminah's sister is beautiful (we can presuppose Aminah exists and she has a sister).

2. John's book is thick (we can presuppose John exists and he has a book).

3. Anto's problem (we can presuppose Anto exists and he has a problem).

4. The house is yellow (we can presuppose the house exists and it has yellow color).

5. Thompson's great idea (we can presuppose Thompson exists and he has great idea).

II. Factive Presupposition; It is the assumption that something is true due to the presence of some verbs such as "know" and "realize" and of phrases involving glad

1. I am glad you make it (we can presuppose you make it).

2. Everybody knows Jokowi is a President (we can presuppose that Jokowi is a President).

3. Many people know Rebecca as a best singer (presuppose that Rebecca is a best singer).

4. Rudi knows that Susan is very fat (we can presuppose that Susan is fat).

5. Most people realize that being patient is better than doing revenge (we can presuppose that patient is better than doing revenge).

III.Non Factive Presupposition; It is an assumption that something is not true. For example, verbs like "dream", "imagine" and "pretend" are used with the presupposition that what follows is not true.

1. Rudi dreamed that he won the lottery (presupposes that Rudi did not win the lottery).

2. It is likely that John came early (presupposes John might/might not come early).

3. It is likely Ratna bought the book (presupposes that Ratna did not buy the book).

4. Robert imagined that he had a beautiful wife (presupposes Robert does not have a beautiful wife).

5. Aram pretended that he smoked (presupposes that Aram did not smoke).

IV.Lexical Presupposition; It is the assumption that the speaker can act as if another meaning (word) will be understood.

1. Ratna stopped singing (presupposes Ratna used to sing).

2. Joko stopped loving her (presupposes Joko used to love her).

3. Richard is late again (presupposes Richard was late before).

4. Arman managed to do something (presupposes Arman succeeded in some way).

5. Rudi is smoking again (presupposes Rudi smoked before).

V. Structural presupposition; It is the assumption associated with the use of certain words and phrases. For example, wh-question in English are conventionally interpreted with the presupposition that the information after the wh-form(e.g. when and where) is already known to be the case.

1. When did Sarah leave? (presupposes that Sarah left).

2. Where did Ratih buy this book (presupposes that Ratih bought a book).

3. When did Susan travel to Bangkok ? (presupposes Susan travelled).

4. When did Susan cry? (presupposes Susan cried). 
5. When did Tina cook? (presupposes Tina cooked).

VI.Counterfactual; It is the assumption that what is presupposed is not only untrue, but is the opposite of what is true, or contrary to facts.

1. If I were his friend I would help him (presupposes that I am not his friend).

2. If you were my son, I would not allow you to do it (presupposes you are not my son).

3. If you were my sister, I would buy you this dress (presupposes you are not my sister).

4. If you were my daughter, I would not let you go (presupposes you are not my daughter)

5. If I were you, I would make it happened (presupposes I am not you).

\section{Conclusuion}

It is always interesting to talk about communication. In this research, Mario Teguh used all types of pragmatic presupposition such as; existential presupposition, factive presupposition, lexical presupposition, structural presupposition, a non factive presupposition, and a counter factual presupposition. Shared knowledge is very important to make inference. In this program, Mario Teguh, as the speaker, has shared knowledge between him and audiences. So, he explained and served information pertinent to the topic. This shared knowledge will help him in giving a motivation. Mario Teguh, as the speaker, used presupposition before making an utterance in this program. We also use presupposition in a conversation in our daily life. Knowing pragmatic presupposition helps us to know the utterance well, that way we can make a good communication with people because there is no misunderstanding between people during communication..

\section{References}

Cruse, A. (2006). A Glossary of Semantics and Pragmatics. Edinburgh: Edinburgh University Press Ltd.

Cruse, A. (2000). Meaning in Language: An Introduction to Semantics and Pragmatics. Oxford: Oxford University Press.

Fromkin, V., Rodman, R., and Hyams, N. (2011). An Introduction to Language (9th Edition). Wadsworth: Cengage Learning.

Gadzar, G. (1979). Pragmatics: Implicature, Presupposition and Logical Form. New York: New York Academic Press.

Levinson, S. C. (1983). Pragmatics. Cambridge: Cambridge University Press.

Levinson, S. C. (1995). Pragmatics. Cambridge: Cambridge University Press.

Sperber, D. (2006). Pragmatics, in F. Jackson and M. Smith eds., Oxford Handbook of Philosophy of Language.

Yule, G. (1996). Pragmatics, New York: Oxford University Press. 